\title{
A Tribute to Barocco: The Figurativeness of Maria Morska
}

\begin{abstract}
It was the evening of 29th of November. The café was swarming with people. I came in very embarrassed, said hallo to Raab and I was trying to hide somewhere on the side but Serafinowicz took me out of my hiding place and made me take a seat at the general artistic table where, apart from other people who I had already known, there was also "Picador's only daughter", Ms Maria Morska 1 .
\end{abstract}

Jarosław Iwaszkiewicz recalls the first meeting in the 'Pod Picadorem' café in this simple way, perhaps too simple, taking into account that what is just unfolding is the birth of Skamander and, in fact, of the whole new Polish poetry. It is extraordinary and meaningful that one of the few people that the memory of the author of Oktostychy connected with that moment is Maria Morska. Julian Tuwim recalls that on 29 November she recited the poem titled Alles, alles über Deutschland by Antoni Słonimski and - after the meeting in a quite relaxed atmosphere when the artists went to 'Turek' to have shish kebab and coffee, and Tadeusz Raabe was dancing a jig on the table - Morska was singing some beautiful French song².

And so she was with the Skamanders from the very beginning. After the poetic world reacted to the call: "Young Warsaw artists unite!!!", her declamation was the central point of the performance which took place every

\footnotetext{
1 J. Iwaszkiewicz, Książka moich wspomnień, Kraków 1968, pp. 196 [Unless indicated otherwise, quotations and titles in English were translated from Polish].

2 J. Tuwim, Nasz pierwszy wieczór, "Wiadomości Literackie" 1926, no. 51/52, p. 2. According to Iwaszkiewicz, the poem in question was performed by Słonimski himself.
} 
day between 9 and 11 p.m., first in a café in Nowy Świat, and then in the basement of Hotel Europejski ${ }^{3}$. She assisted the poetry created with youthful energy: she was first to spontaneously present the works to the public; works which Tuwim will later call "juicy, muscular, with a kind of athletic (...) «straddle»"4. She was where young art was stomping, thundering, and smoking, where "poetic tents were put up", and exactly where artists of the generations to come would derive boldness, rebellion, and authenticity from. Apart from poems by the Pikador poets, Morska recited Mickiewicz, Norwid, Leśmian ${ }^{5}$. Her likings and tastes were original, sometimes incomprehensible to her friends. Iwaszkiewicz writes:

\begin{abstract}
This beautiful woman, so similar to an artificial flower, has always made me feel uneasy with the atmosphere she created around her, saturated with the oriental smell of cinnamon and myrrh, full of fanatical worship for poems which I did not think much about. It was Tuwim and I who showed her the fascinating beauty of The Drunken Boat by Rimbaud in the translation into Polish by Miriam. She preferred Leśmian and Théodore de Banville ${ }^{6}$.
\end{abstract}

She recited unnaturally, with exaggeration, in a high-pitched or even squeaky voice. In his review of a poetic evening with the participation of Morska, Tadeusz Boy-Żeleński calls her voice "strange", "metallic", "as if deliberately artificial", "predatory". It seems that the originality of her declamation causes him certain trouble. For a long time, the reviewer keeps looking for the justification of the pleasure derived from listening to the voice of the reciter. He saves the day using humour.
(...) I would be an unskilful flatterer if I praised Ms Morska for simplicity when she consciously avoids it. On the contrary, her aim is - it seems to me - to evoke a feeling of anxiety; rape the sensitivity of the audience with the constant fortissimo of her accent, her gesture, not to allow them to take a short nap on the pillow of easy decadence. There are works where it has an excellent effect: e.g. Podróż (Journey) by Słonimski, Garbus (Hunchback) by Tuwim or those pretty little poems by Maria Pawlikowska. In others, like in the poem "without a title" by Lechon, this vivid instrumentation clashes with the text craving for simplicity. Anyway I long to hear Morska again, I would like to listen to that predatory voice. I did not use to be a decadent for nothing?.

Irena Krzywicka, a friend of Morska, recollects her recitation with the use of diminutives: "She declaimed a teeny bit artificially, but with her own idiosyncratic manner, drawling words with her little sweetened voice"

\footnotetext{
${ }^{3}$ J. Stradecki, W kręgu Skamandra, Warszawa 1977, pp. 48-49.

4 J. Tuwim, op.cit., p. 2.

5 J. Stradecki, op.cit., p. 49.

6 J. Iwaszkiewicz, Aleja przyjaciót, Warszawa 1984, p. 77.

7 T. Boy-Żeleński, Wieczór recytacyjny Marii Morskiej i Stefana Jaracza z udziałem poetów Skamandra, [in:] idem, Flirt z Melpomena, Pisma, vol. XXII, pp. 586-587.

${ }^{8}$ I. Krzywicka, Wyznania gorszycielki, Warszawa 1996, p. 108.
} 
Iwaszkiewicz is rather critical when commenting on one of the artist's performances: "Morska created some kind of disagreeable mannerism, made an array of mistakes, such as illustrating the recited poem with gestures" . Jerzy Liebert, perhaps the most resistant one to the artist's charm, looks at Morska in yet another way after several years after her triumphs in 'Pod Picadorem', and his characteristics includes expressions such as "lunatic", "hysterical woman", "exalted"10.

She was a muse of interwar poets, a friend and teacher of the greatest artists of the epoch, an erotic fascination for men and women. Readers encouraged by this popularity and wishing to follow Maria Morska (actually: Maria Frenkiel-Knasterowa) through historical documents will soon find out about the scarcity of biographical materials. The artist flitted through history like a ghost: there are hardly any original documents left that would allow for sequencing the knowledge about her education, time of getting married, artistic life. Morska is often elusive even in the photographs: she hides under the brim of a large hat or escapes into the shade of the frame. This 'elusion' and confusion can be also found in the sources. Problems with identification are also caused by the popularity of her assumed name in the theatrical environment of that time (Adolfina Morska, Janina Morska, Gabriela Morska-Popławska) ${ }^{11}$. Kazimierz Wroczyński notes yet another surname of the artist: Strońska. This information is quoted after Wroczyński by Jadwiga Zacharska in Skamander, although she prefers the correct version ${ }^{12}$.

In 2008, Hanna Faryna-Paszkiewicz devoted a decent monograph to the "Skamander's only daughter". Still, numerous and diversified sources which she quotes are fragments, excerpts. Paszkiewicz admits that her work is "a draft for the portrait of Maria Morska, an incomplete puzzle the details of which will be probably never found, consisting of few fragments of various importance and information"13.

Therefore, this is the only Morska that survived: remembered in a moment, in the meeting, in the detail. Seen in the moments of greatest delight, fascination - or, on the contrary, referred to incidentally, in the background. She is referred to in either euphoric or marginal, casual comments.

And this is practically all. Nevertheless - taking into account the traces of the artist in her friends' texts - letters and entries in diaries are merely part of documented memories. It is poetry that remains: an area which is the richest in meanings and at the same time the most difficult to verify. There is the book of poetry titled Paryż (Paris) by Pawlikowska - all dedicated to the "charming interpreter" as a "cordial gift" - and other poems of the author of Pocatunki (Kisses) as well as occasional works by the Skamander poets - e.g. Iwaszkiewicz - and, naturally, poems by Słonimski, whose

${ }^{9}$ J. Iwaszkiewicz, Książka moich wspomnień, ibid., p. 197.

${ }^{10}$ Liebert expresses his opinions in his letters written to Jarosław Iwaszkiewicz and Anna Iwaszkiewicz in March 1926. Cf. J. Liebert, Pisma zebrane, vol. II, Warszawa 1976, p. 192, 400. After: H. Faryna-Paszkiewicz, Opium życia. Niezwykła historia Marii Morskiej - muzy skamandrytów, Warszawa 2008, pp. 29-30.

11 Ibid., p. 13.

12 Cf. J. Zacharska, Skamander, Warszawa 1977, p. 14.

${ }^{13}$ H. Faryna-Paszkiewicz, op.cit., pp. 10-11. 
muse and protagonist, undisclosed by name, was known to the artist's friends beyond any doubt.

Iwaszkiewicz recalls: "Antoni wrote beautiful poems for Maria"14 and there is not even an echo of hesitation to be heard, there is not a trace of methodological storms around "the error of intention". Krzywicka simply writes about the poet's love: "it was known". After many years, Julia Hartwig uses passive voice to that same end in her conversation with Joanna Kuciel-Frydryszak: "It was not talked about but it was common knowledge that Morska was Antoni's great love (...). I think that it must have been painful for Janka"15. Słonimski's feeling and its impact on his works could not have been a secret for the society from the 'Pod Picadorem' café Anna Iwaszkiewicz, when relating her meeting with Morska to her husband, uses a quotation from the poem titled Inwokacja (Invocation):

\begin{abstract}
You would never have guessed who I met today in the tobacco shop where I was buying postcards... Imagine it was the one whose eyes are "enormous, ardent and pure" (.... ${ }^{16}$.
\end{abstract}

The specific, somewhat behind-the-scenes aura around the poet's fascination with Morska - due to either his consistent silence on that subject during his whole life, or surprising discretion of his friends (surely indiscreet in other matters) - makes it more difficult to understand what relationship Słonimski actually had with the artist. Impersonal forms such as "it was talked about, it was known" as well as avoiding authentication for speculations and rumours all foster mythisation and exotisation. In any case, the picture of the feeling preserved in letters and notes is surprisingly coherent with the impression which Morska made on the authors of memories. As a result, Słonimski's "great love", which the reader learns about today, no longer belongs only to the author of Godzina poezji (The Hour of Poetry), but it becomes solidly underpinned with the fascination experienced by the whole literary community of that day.

One more certain trace of the relationship between Słonimski and Morska can be found in Dzienniki (Diaries) by Anna Iwaszkiewicz. The record of a conversation - touching for both of them - is the only document on this subject in which the poet can be heard. In the account of Anna Iwaszkiewicz, Słonimski seems to be helpless in the face of the overwhelming, magnetic influence of Morska. At the same time, however, the authoress confirms the mutuality of their feeling.

He told me from the beginning about this unknown painful and wonderful story of love, love of two people being on such a level that they would not be able not to harm others to achieve happiness. He told me how they

\footnotetext{
${ }^{14}$ J. Iwaszkiewicz, Aleja przyjaciót, op.cit., p. 80.

15 J. Kuciel-Frydryszak, Stonimski. Heretyk na ambonie, Warszawa 2012, p. 46.

16 A. Iwaszkiewicz, J. Iwaszkiewicz, Listy 1922-1926, eds. M. Bojanowska, E. Cieślak, Warszawa 1998, p. 354.
} 
deluded themselves with the possibility of friendship, only friendship, what torment they suffered, feeling that they belong to each other for life ${ }^{17}$.

Even if there is some doubt concerning the equal strength of emotional involvement between Słonimski and Morska, this fascination was not one-sided.

Could one agree with Iwaszkiewicz that "Antoni wrote poems for Maria"? And even if this is adopted as a hypothesis, with a few reservations - securing oneself with the notions of "the author's signature" or "weak subject" - could one learn something about a person when knowing only poetry which she inspired? The poems focused around the artist - those, for which she was both the magnet and the centre - provoke one to reconstruct at least the impression she made.

We enter here into the region of speculation and guesswork (almost "great heresy"). It is precisely on such margins of reading that the reception of poetry can become a real "thing of imagination".

I will quote the aforementioned poem by Słonimski. It is known under two titles: Inwokacja (Invocation), which appears in the volume titled Godzina poezji and is repeated by the London selection of the author's poems from $1944^{18}$. The second version comes with the title Do Wiktorii Colonny (To Vittoria Colonna); this one seems to come from a later time. It appears, for instance, in the author's Wybór poezji (A Selection of Poetry) from 1965.

\section{Do Wiktorii Colonny}

Jeśli Cię Michał Anioł porównał do słońca,

A siebie do blednącej upodobnił luny,

Jeśli Cię boski Ronsard wysławiał bez końca,

Niezmordowaną ręką w złote bijąc struny,

Jeśli Cię już nazwano słońcem, różą wonną,

Jeśli Cię porównano do dźwięczącej lutni,

Ja dla Ciebie, o Mario Wiktorio

Colonno,

Sięgnę wyżej i nazwę Cię smutniej!

\section{To Vittoria Colonna}

If Michelangelo compared you to the sun,

And himself likened to a fading moon,

If divine Ronsard praised you with no end,

Striking gold strings with his tireless hand,

If you were called the sun, sweet-scented rose,

If you were compared to resonant lute,

For you I will, oh Maria Vittoria Colonna,

Reach higher and call you more sorrowful!

17 A. Iwaszkiewicz, Dzienniki, Warszawa 1993, p. 68.

${ }^{18}$ Cf. A. Słonimski, Godzina poezji, Warszawa 1923; A. Słonimski, Wybór poezji, London 1944. 
Tyś jest jak miasto wielkie, czarne i krzykliwe,

Gdzie się stu czartów śmieje - płacze stu aniołów.

Oczy Twe są ogromne, czyste i żarliwe,

Jak dwie wieże podniebne strzelistych kościołów.

Nie obejmę Cię wielkiej, a jako cień lotnej,

Choćby rozpiął ramiona i natężył siły,

I pragnę - wciąż samotny, Ciebie wciąż samotnej.

Ciebie, lutni mej, róży, gwiazdy i mogiły.
You are like a city, big, black and loud where

A hundred devils laugh - a hundred angels cry.

Your eyes are enormous, ardent and pure,

Like soaring towers of lofty churches.

I will not embrace you, great and ethereal,

Even if I stretch my arms and strain my arms,

I - still lonely - want you - still lonely.

You, my lute, my rose, my star and grave.

Słonimski's silence about Morska is consistent: it includes not only discretion in conversations with his friends and the absence of the artist in his memories. The poet also hides his muse in poetry: in the example quoted above he gives her a pseudonym in the title of the work. Vittoria Colonna, a 16th-century poetess, a friend of Michelangelo, obviously remains beyond suspicion of inspiring the passionate feeling, being a "lute, rose, star, and tomb". At the same time, Słonimski's mysterious dedication seems to be easy to decipher: Colonna is similar to Morska with regard to her versatile education, intellectual independence, and inspiring creative friendship with the artist $^{19}$.

The apostrophe at the end of the second stanza is rather characteristic: "Oh Maria Vittoria Colonna". Uttering the name of Morska in this poetic mystification may have brought Słonimski some relief. Both characters, named and unnamed, connect and assimilate with each other. The duplication is symmetrical: Colonna enriches Morska to the same extent as Morska enriches Colonna ${ }^{20}$. The renaissance poetess is referred to as only "Vittoria" by Leopold Staff, the author of the first translations of Buonarotti's poetry published in 1922, so shortly before Godzina poezji Staff writes about the impact of Colonna on the author of David:

Michelangelo, who never allowed to take control of himself, yields with confidence and submissiveness to her hands like an inert material. It was

19 Vittoria Colonna (1490-1547), [in:] Dawne ptomienie. Mała antologia włoskiej poezji miłosnej, translation and selection by A. Kuciak, introduction by P. Salwa, biograms and edition of the Italian part by A. Jankiewicz, Warszawa 2008, p. 76.

${ }_{20} \mathrm{In}$ anthologies and textbooks, the 16th-century artist is presented only with the name Vittoria. Cf. J. Heistein, Historia literatury włoskiej, Wrocław-Warszawa-Kraków 1987, p. 106; K. Żaboklicki, Historia literatury włoskiej, Warszawa 2008, p. 141. 
unearthly love, love of spirits, undisturbed by any breath of the earth.

Friendship and affection bound them with knots of Christian faith. ${ }^{21}$

Michelangelo sees a spiritual guide in his muse, the one who is capable of answering his religious anxieties, lifting from doubt. Morska is also Słonimski's guide, albeit not a religious one: she supplements shortcomings in his education, shapes his opinion on current events, sometimes summarises new books. As Krzywicka notes, "Niuta was a woman who was not only nice but also extremely good, immensely intelligent and well-read. She was a source of knowledge for somewhat ignorant Tolek who was, nevertheless, blessed with infallible taste and intuition" ${ }^{\prime 22}$. There is one more thing that the two women from the poem have in common: both are faithful to other men (Morska to her husband, while Colonna is a widow writing poems for her deceased husband, and also unites in spiritual bonds with Christ) as well as they are beyond the reach of their admirers. This is probably why the (real) addressee of the poem still escapes attempts to characterise her; she goes beyond magnifying, paradoxical formulas. She is neither the laughter of devils, nor the cry of angels. It is also impossible to embrace her with stretched arms and all the strength (this attempt seems to repeat the effort of Adam Mickiewicz's Konrad Wallenrod from the Great Improvisation fragment - "The moment of destiny has come today / I will strain the arms of my soul as I may"23). This is why the superlative of admiration seems to be not adoration, but sorrow ("For you I will (...) / Reach higher and call you more sorrowful"). This is sorrow of elusiveness, unfulfilled desire, and the biggest paradox of unhappy feeling - shared loneliness.

In the period of the birth of 'Pikador', Słonimski - as Iwaszkiewicz said - "only existed, as if, in her [Morska's] shade, he moved in the orbit drawing an arc only around her, he was the echo of her sentences, tastes, sayings and convictions" ${ }^{24}$. After one hundred years, the situation reverses: it is the poet's muse, mysterious today, who is just an echo of his poems. Interestingly, a similar role of a mere reference - a shadow - was given to Colonna in the paintings of Michelangelo. There is a hypothesis that the artist immortalised her in the Sistine Chapel. It is said that the female figure who Madonna from the fresco titled The Last Judgment is looking at has Colonna's face. This figure, hidden behind St. Lawrence, is barely perceptible, though ${ }^{25}$.

How did other Skamander poets remember Morska? Another interesting trace is provided by a poem by Iwaszkiewicz.

${ }^{21}$ L. Staff, Michat Anioł i jego poezje, Warszawa 1977, p. 108.

22 I. Krzywicka, Wyznania gorszycielki, p. 207.

23 A. Mickiewicz, Dziady, part III, Kraków 2010, p. 158.

24 J. Iwaszkiewicz, Aleja przyjaciót, p. 78.

25 A. Cirocka, Vittoria Colonna - muza i przyjaciółka Michała Anioła, https://niezlasztuka. net/o-sztuce/michal-aniol-i-jego-muza-vittoria-colonna/ (accessed: 20.02.2019). 


\section{Marii Morskiej}

Żegnałem heroinę w ukłonach barokko,

Za tło uśmiechów mając wzgórzyste Marokko.

Odeszła - palmom równa na piasku obrusie,

Oddając igrom wiatru tren i pióro strusie.

Zwycięsko na pokoje wracający, dumny -

Oglądam niewolnicę pod cieniem kolumny.

Murzynkę uśmiechniętą, co na Remingtonie,

przepisuje mój sonet o wyblakłym tonie.

\section{To Maria Morska}

I bade the heroine farewell in bows of barocco,

The background of smiles being the hills of Marocco.

She's gone - equal to palms on the tablecloth of sand,

Returning her train and ostrich feather to the wind.

I return to my chambers in victory, all proud -

I watch the slave under the shadow of the column.

A smiling African girl who on the Remington

Keeps on rewriting my sonnet of a faded tone.

The poem shows characteristic features of Iwaszkiewicz's early works, such as images revealing his fascination with the world of the Orient; elaborate, exotic rhymes; a juxtaposition of colourful and odorous exuberance with carefully staged artificiality. Tomasz Wroczyński notices that:

In Iwaszkiewicz's aesthetic inclinations from the Ukrainian period of Oktostychy it is possible to detact fascination with the works by Oscar Wilde, an English prose writer, representing extreme aestheticism. After Wilde Iwaszkiewicz postulates the superiority of art over life, culture over nature. The lexis of Oktostychy turns out to be unusually characteristic, making references to Biznatine ornamentation, imitating the wealth and splendour of iconographic images ${ }^{26}$.

Iwaszkiewicz the aesthete puts on masks on the character's face, presents her in different roles. He dresses her up, arranges stunning scenery, tries different conventions. The meeting of Morocco - famous for aromatic spices and elaborate decorations - with a baroque bow is a quintessence of artificiality; an intriguingly decorative, though incoherent, image which is difficult to visualise: its uniqueness is stressed by the play of rhymes containing foreign sounds (Morocco, barocco). Perhaps the name of the African country also conceals the confirmation of the dedication: this lexeme does not need much to become an anagram of the surname of the addressee (the role of Oktostychy is known in disseminating assonance in Polish poetry).

${ }^{26}$ T. Wroczyński, O twórczości Jarosława Iwaszkiewicza, "Rocznik Towarzystwa Literackiego im. Adama Mickiewicza" 1994, no. 29, p. 90. 
The quoted poem is a poetic definition of grotesque, in which the pathos of heroic farewell against the background of a hilly landscape clashes with the necessity to work on Remington, while the proud heroine, towering like a palm, is capable of transforming herself into a slave hidden in the shade of the column.

The creation of both women (although there is one heroine of the poem) harmonises with the memories of Iwaszkiewicz about Morska: the artist reminded him of an artificial flower, he associated her with the smell of cinnamon and myrrh.

Could Groteska [A Grotesque], written "to Maria Morska", be treated as a proof of recognition for her artistry? In the poem, apart from the humorous play on conventions and juggling with images, one can also notice respect for the fascinating ability to undergo metamorphosis, for Orientalised distinctness. If rewriting a sonnet "of a faded tone" can be compared to declamation, the smiling African woman certainly acquires new, exotic colours for the poem; colours which even the poet-aesthete would not be able to imagine.

The authors of the quoted poems associate Morska with travelling - in time and space. As if she was making them match her originality, invent poetic formula and strategies adequate to her charisma. It seems that she also inspires one to look for pseudonyms and roles which would be able to express the impression of changeability accompanying her; a sense of glimmer, being-different, never the same.

Depicted in poetry in this way, transmuted from the matter of life into the matter of art, she is similar to Morska preserved in memories. Thus Krzywicka's account seems to be rather typical.

I met her (...) on the stairs, she flew down from above and stood almost half way through the stairs, looking me straight in the eye with her sea gaze as if she had been expecting to see me there, and she sked me a question: Have you read the latest poem by Lilka? Morska was in the habit of not talking about trivial things, which was rare in women. Either she had something important to say and this was usually the case, or she was able to be beautifully silent. And then, without much further ado, she began to recite straight away.

Rudą nocą, pod mostem, w Sekwanie Płynie kotka przemokła i sina.

Pod następnym mostem niespodziewanie

Przyłączyła się do niej dziewczyna.
On red night, under the bridge, in the Seine

A cat is swimming, all livid and soaked.

Under the next bridge out of a sudden The cat is joined by a beautiful girl.

We were deeply moved by the piercing beauty of this poem and its terrifying content. Standing on the stairs, we were silent for a long time ${ }^{27}$.

${ }^{27}$ I. Krzywicka, op.cit., pp. 235-236. 
Wyznania gorszycielki (The Confessions of a Scandalist) is a work that seizes on the halo of clandestinity that accompanies the artist. It seems that in the impression which she made, her ability to instantly sublimate the ordinariness into figurativeness was of utmost importance; that moving on to poetic substance while excluding that which is merely a convention. This ability brings to mind the invention of performance art, in which the artist treats themselves (and their body) as a tool of art, whereas the recipient, knocked out of the formula of behaviour known to them - involved in a new stunning reality - has to face otherness.

Hence, perhaps, the intensity of "experiencing" Morska. The poetic records of the impression which she made resemble the reception of works of art. The literary image of the "Skamander's only daughter" is a testimony to a moment of delight, an illumination, and - possibly most importantly - a spontaneous, artistic co-participation. Anna Iwaszkiewicz, being under the powerful spell of Morska, writes:

I have the impression that I saw her as if in some fog, like you see the audience playing on the stage of an amateur theatre; you only feel stage fright and such strange unconsciousness in which the words of the role come out, as if mechanically, of ourselves. When I left I thought that this charm was gone. I did not feel any emotion, I still had her in front of my eyes and again I kept seeing her eyes, her extraordinary, incredibly beautiful, terrifying eyes. ${ }^{28}$

The accounts of the artists of the epoch are dominated by the impression that Morska's declamation deteriorated with time. As Iwaszkiewicz recalls, "The reciter no longer enjoyed popularity in the following years. The scarcity of her performances in front of the public caused that stage fright hampered her inborn temperament." 29 In the late 1920s, the artist gave up her stage career and from 1924 wrote columns to Wiadomości Literackie under the name of Mariusz Dawn. She returned her "train and ostrich feather" and appeared in a new role instead: that of a shrewd observer involved in political and social affairs.

It is worth finishing the search for Morska in poetry with a text which she often used to declaim: Le Saut du tremplin (The Leap from the Springboard) by Théodore de Banville in the translation by Miriam. Characteristically, Iwaszkiewicz remembered not its title but the incipit - as if, after years, he could still hear the artist's voice. He mentions the wonderful clown rather than the leap from the springboard both in Aleja przyjaciót (The Avenue of Friends) as well as in Ksiazka moich wspomnien (The Book of My Memories). Morska's magic requires me to include at least a fragment of the work evoking the muse of the 'Pikador' poets, since the reciter's artistic directness is the praise of poetry: a bold leap from the springboard "up to the unknown heights", a flight among the stars.

\footnotetext{
28 A. Iwaszkiewicz, Dzienniki, p. 81.

29 J. Iwaszkiewicz, Książka moich wspomnień, p. 197.
} 
(...)

“Wciąż w górą, w dal, pod niebios sklep!

Aż w te lazury, których step

Ruchomej turmy naszej dachem!

Aż po tych Wschodów krwawych próg,

Zkąd płomienisty wstaje bóg,

Szalony gniewem i przestrachem.

Wyżej, wciąż wyżej! jeszcze stąd Giełdziarzy w złocie widzę rząd, Krytyków, panny żądne sideł I realistów świat napłask.

Powietrza! światła! w błękit! w blask! Ach, skrzydeł! skrzydeł! skrzydeł! skrzydeł!"

I z giętkiej deski swej, jak ptak, Klown wzbił się w lot szalenie tak, Że śród powietrznej przebił jazdy

- Przy wrzawie trąb - płócienny dach

I, w pragnień swych wciąż tonąc snach,

Potoczył się pomiędzy gwiazdy.
(...)

Higher still, up to the pure sky To that lapiz lazuli whose azure Covers our moving prison!

To those rosy orients

Where blazing Gods walk about, Mad with anger and fright.

Higher, higher still! from here I see a row of stockjobbers in gold, Critics, maids greedy of snares And the world of realists all flat. Higher! further! air! the blue! Wings! wings! wings! wings!

And from his bendy springboard, like a bird,

The clown took off so madly that In his aerial ride he punctured

- With din of trumpets - the canvas roof

And, still drowning in his dreams, Bowled up among the stars.

\section{REFERENCES}

Boy-Żeleński T., Wieczór recytacyjny Marii Morskiej i Stefana Jaracza z udziałem poetów Skamandra, [in:] T. Boy-Żeleński, Flirt z Melpomena. Pisma, vol. XXII, pp. 586-587.

Faryna-Paszkiewicz H., Opium życia. Niezwykła historia Marii Morskiej - muzy skamandrytów, Warszawa 2008.

Heistein J., Historia literatury włoskiej, Wrocław-Warszawa-Kraków 1987.

Iwaszkiewicz A., Dzienniki, Warszawa 1993.

Iwaszkiewicz A., Iwaszkiewicz J., Listy 1922-1926, eds. M. Bojanowska, E. Cieślak, Warszawa 1998.

Iwaszkiewicz J., Aleja przyjaciót, Warszawa 1984.

Iwaszkiewicz J., Książka moich wspomnień, Kraków 1968.

Krzywicka I., Wyznania gorszycielki, Warszawa 1996.

Kuciel-Frydryszak J., Słonimski. Heretyk na ambonie, Warszawa 2012.

Liebert J., Pisma zebrane, vol. II, Warszawa 1976.

Mickiewicz A., Dziady, cz. III, Kraków 2010.

Słonimski A., Godzina poezji, Warszawa 1923.

Słonimski A., Wybór poezji, London 1944. 
Staff L., Michat Aniot i jego poezje, Warszawa 1977.

Stradecki J., W kręu Skamandra, Warszawa 1977.

Tuwim J., Nasz pierwszy wieczór, “Wiadomości Literackie” 1926, no. 51/52.

Vittoria Colonna (1490-1547), [in:] Dawne płomienie. Mała antologia włoskiej poezji mitosnej, translation and selection by A. Kuciak, introduction by P. Salwa, biograms and edition of the Italian part by A. Jankiewicz, Warszawa 2008.

Wroczyński T., O twórczości Jarosława Iwaszkiewicza, "Rocznik Towarzystwa Literackiego im. Adama Mickiewicza" 1994, no. 29, p. 90.

Żaboklicki K., Historia literatury włoskiej, Warszawa 2008.

\section{SUMMARY}

The paper focuses on the figure of Maria Morska, a reciter dubbed "Skamander muse", who had a versatile and multifaceted impact on the literary circles of her day. I am conducting the quest for the artist (elusive today in the face of scarce biographical sources) through interpreting the poems for which she was a magnet and a centre (i.e. Inwokacja by Antoni Słonimski and Groteska by Jarosław Iwaszkiewicz). The image of Morska emerging from them presents a very original figure: one that was admired and received intensely.

The poetic inscriptions of the impression which the Skamander muse made often bring to mind the reception of works of art. Morska refines commonness into a metaphor. Her literary image is a testimony to a moment of delight, dazzle, and - perhaps more importantly - spontaneous, artistic co-participation. She inspires one to look for pseudonyms and roles which would be capable of expressing the impression that accompanied her - one of changeability, glimmer, being different, never being the same.

\section{Keywords}

Maria Morska, Anna Iwaszkiewicz, Jarosław Iwaszkiewicz, Antoni Słonimski, Skamander, Skamander's muse, poetry

\footnotetext{
Agata Szulc-Woźniak - a PhD student in the Faculty of Polish and Classical Philology at Adam Mickiewicz University in Poznań. Her research interests include Polish 20th-century poetry. She prepares her PhD dissertation on Joanna Pollakówna. She published in, for instance, "Ruch Literacki" and "Konteksty Kultury".

e-mail: agata_szulc@onet.pl
} 